\title{
Józef Kubicki
}

\section{Akta Stolicy Apostolskiej za rok 1958}

Prawo Kanoniczne : kwartalnik prawno-historyczny 2/1-2, 3-32

1959

Artykuł został zdigitalizowany i opracowany do udostępnienia w internecie przez Muzeum Historii Polski w ramach prac podejmowanych na rzecz zapewnienia otwartego, powszechnego i trwałego dostępu do polskiego dorobku naukowego i kulturalnego. Artykuł jest umieszczony w kolekcji cyfrowej bazhum.muzhp.pl, gromadzącej zawartość polskich czasopism humanistycznych i społecznych.

Tekst jest udostępniony do wykorzystania w ramach dozwolonego użytku. 


\section{$\begin{array}{lllllllll}\mathbf{D} & \mathbf{O} & \mathbf{K} & \mathbf{U} & \mathbf{M} & \mathbf{E} & \mathbf{N} & \mathbf{T} & \mathbf{Y}\end{array}$}

\section{AKTA STOLICY APOSTOLSKIEJ ZA ROK 1958}

\section{Acta Pii Papae XII.}

A. Litterae Encyclicae.

1. „Meminisse iuvat”, dn. 14 lipca 1958 r. N. 9-10, pp. $449-459$.

W okresie strasznych zmagań ludów poświęciliśmy rodzaj ludzki Niepokalanemu Sercu Matki Bożej. Dziś, kiedy brak pokoju, niechaj wszyscy wierni zgromadzą się wokól ołtarzy na nowennę do Wniebowzięcia Najśw. Maryi P. i proszą o łaski dla znękanej ludzkości, a szczególnie dla najbordziej cierpiących, by światło Boże oświeciło umysły ludzkie i zapanowała miłość, braterskość i sprawiedliwość.

B. Constitutiones Apostolicae.

a) Utworzenie nowych hierarchii.

1. Spinensis eparcii $z$ wik. patrialchalnego syryjskiego, dn. 15 lipca 1957 r. N. 4, pp. 141-143.

2. Egzarchatu apostolskiego dla Rosjan rytu bizantyńskiego zamieszkałych w Anglii i Walii, dn. 10 czerwca 1957 r. N. 8, pp. $345-347$.

b) Utworzenie nowych diecezji.

1. Berytensis z terenów podległych administracji St. Apost. w Libanie, dn. 3 lipca 1957 r. N. 1, pp. 27, 28.

2 i 3 Campi Grandis i Auropolitana $z$ diec. Corumbensi i prałatury udzielnej Registrensi w Brazylii, dn. 15 czerwca 1957 r. N. 2-3, pp. 57-60. 
4. Januarensis $\mathrm{z}$ diec. Montisclari i prałatury udzielnej Paracatuensis w Brazylii, dn. 15 czerwca $1957 \mathrm{r}$. N. 2-3, pp. $60-62$.

5. Musomensis z pref. apost. tejże nazwy w Afryce Brytyjskiej, dn. 5 lipca 1957 r. N. 4, pp. 137-139.

6. Tapacalensis $z$ diec. Chiapasensis $w$ Meksyku, dn. 21 czerwca 1957 r. N. 5, pp. 185-187.

7. Torreonensis $z$ diec. Saltinensis $w$ Meksyku, dn. 21 czerwca 1957 r. N. 5, pp. 188-190.

8. Victoriensem de Conquista $z$ diec. Amargonensis w Brazylii, dn. 27 lipca 1957 r. N. 5, pp. 193-195.

9. Aleppensis z terenów podległych adm. St. Ap. w Syrii, dn. 3 lipca 1957 r. N. 6-7, pp. 149-151.

10. Malaniensis $z$ archidiec. Luadensis i diec. Silvae Portuensis w Portugalii, dn. 25 listopada 1957 r. N. 6-7, pp. $300-302$.

11. Copiapoensis $\mathrm{z}$ dotychczasowej prałatury udzielnej w Chile, dn. 31 października 1957 r. N. 8, pp. 347-349.

12. Novae Ulmae $z$ archidiec. S. Pauli De Minnesota $w$ Stanach Zjednoczonych Am. Płn., dn. 22 listopada 1957 r. N. 8, pp. 351-353.

13. Urawaensis $\mathrm{z}$ dotychczasowej pref. apost. $\mathrm{w}$ Japonii, dn. 16 grudnia 1957 r. N. 11, pp. 505-507.

14 i 15. Palmensis i Xapecoensis $z$ dotychczasowej prałatury udzielnej Palmensis i diec. Lagensis $w$ Brazylii, dn. 14 stycznia 1958 r. N. 11, pp. 507-510.

16. Guarandensis $\mathrm{z}$ diec. Rivibambensis $\mathrm{w}$ Ekwadorze, dn. 29 grudnia 1957 r. N. 12-13, pp. 553-555.

17 i 18. Cachoeirensis de Itapernirim i S. Mathaei z diec. Spiritus Sancti, która podniesioną została do godności archidiec. w Brazylii, dn. 16 lutego 1958 r. N. 14-15, pp. $665-668$.

19. Matamorensis $\mathrm{z}$ diec. Civitatis Victoriae w Meksyku, dn. 16 lutego 1958 r. N. 14-15, pp. $713-715$. 
20. Acapulcanae $\mathrm{z}$ diec. Chilapensis $\mathrm{w}$ Meksyku, dn 22 marca 1958 r. N. 14-15, pp. 716-718.

21. Tangaensis $z$ dotychczasowej pref. apost. w Afryce, dn. 24 lutego 1958 r. N. 19, pp. 926-927.

c) Utworzenie nowych wik. apost.

1. Esmeraldensis $z$ dotychczasowej pref. apost. w Ekwadorze, dn. 14 listopada 1957 r. N. 8, pp. 349-351.

2. Thakhekensis $z$ dotychczasowej pref. apost. $w$ Laosie, dn. 24 lutego 1958 r. N. 12-13, pp. 617-619.

d) Utworzenie pref. apost.

1. Pacensis $\mathrm{z}$ wik. apost. Confinioris w Kalifornii, dn. 13 lipca 1957 r. N. 4, pp. 139-141.

2. Kengen $\mathrm{z}$ wik. apost. Kikuitensis i Kisantuensis w Kongo Belgijskim, dn. 5 lipca 1957 r. N. 5, pp. 190-192.

3. Dorumaensis $z$ wik. apost. Niangaraensi w Köngo Belgijskim, dn. 24 lutego 1958 r. N. 12-13, pp. 619-621.

d) Utworzenie nowych praiatur udzielnych.

1. Obidensis $z$ prał. udziel. Santaremensis w Brazylii, dn. 10 kwietnia 1957 r. N. 1, pp. 24-26.

2. Juliensis $\mathrm{z}$ diec. Puniensis $\mathrm{w}^{\top}$ Peru, dn. 3 sierpnia 1957 r. N. 4, pp. 144, 145.

3. Caraveliens $z$ archidiec. Arequipensis i diec. Ayacuquensis $\mathrm{W}$ Peru, dn. 21 listopada 1957 r. N. 6-7, pp. 297-299.

4. Carolinensis $z$ prał. udziel. S. Josephi de Grajau w Brazylii, dn. 14 stycznia 1958 r. N. 12-13, pp. $615-617$.

5. Tarnensis $z$ diec. Huanucensi i Huancayensi $w$ Peru, dn. 15 maja 1958 r. N. 17, pp. 842-844. 
6. Huariensis $\mathrm{z}$ diec. Huanucensi i Huarazensi w Peru. dn. 15 maja 1958 r. N. 17, pp. 844-846.

e) Różne:

1. Papieski Instytut Pasterski w Rzymie, dn. 3 marca 1957 r. N. $9-10$, pp. $460-465$.

2. Podniesienie do godności kolegiaty kośc. par. Najśw. Maryi P. Leonensis w Meksyku, dn. 25 marca $1958 \mathrm{r}$. N. 19, pp. 928-930.

D. Litterae Apostolicae.

a) Nadianie tytutów i przywilejów bazyliki mniejszej.

1. Kościołowi parafialnemu Najśw. Maryi Panny w Konstancji diec. Friburgensis, dn. 30 maja 1955 r. N. 2-3, pp. 63,64 .

2. Kośc. Najśw. Maryi P. Łaskawej w Benewencie, dn. 7 czerwca 1957 r. N. 2-3, pp. 64, 65.

3. Kośc. par. św. Juliana męcz. w Brioude diec. Anicensis, dn. 26 kwietnia 1957 r. N. 2-3, pp. 112, 113.

4. Kośc. Najśw. Maryi Panny w Oristono (Sardynia) archidiec. Arborensis, dn. 26 kwietnia 1957 r. N. 4, pp. 147, 148.

5. Kośc. opackiemu Najśw. Maryi P. Casamarensis we Włoszech, dn. 1 czerwca 1957 r. 5, pp. 198, 199.

6. Kośc. par. św. Antoniego Managuensis w Nikaragui, dn. 14 czerwca 1947 r. N. 5, pp. 199, 200.

7. Kośc. par. Najśw. Maryi P. Niepok. Pocz. Viltinensis, dn. 6 sierpnia 1957 r. N. 6-7, pp. 304, 305.

8. Kośc. par. Najśw. Maryi P. Wniebowziętej w Santa Maria a Vico we Wloszech, dn. 30 sierpnia $1957 \mathrm{r}$. N. 8, pp. 354, 355.

9. Kośc. Najśw. Maryi P. Wnieb. W-Randazzo na Sycylii, dn. 20 września 1957 r. N. 8, pp. 358, 359. 
10. Kośc. katedr. Najśw. Maryi P. Wnieb. W Valaterra we Włoszech, dn. 30 listopada 1957 r. N. 9-10, pp. 444, 445 .

11. Kośc. Zaśnięcia Najśw. Maryi P. na Górze Sion. dn. 19 lipca 1957 r. N. 9-10, pp. 469, 470.

12. Kośc. św. Frygidusa w Luce we Włoszech, dn. 30 listopada 1957 r. N. 9-10, pp. 471, 472.

13. Kośc. par. Najśw. Maryi P. w Mediolanie, dn. 30 grudnia 1957 r. N. 9-10, pp. 473, 474.

14. Kośc. katedr. Najśw. Maryi P. Wnieb. Melphiensis, dn. 31 stycznia 1958 r. N. 9-10, p. 476.

15. Kośc. św. św. Wirona, Plechelma i Otgara na Sint-Odilienberg w Batawii, dn. 5 lipca 1957 r. N. 11, pp. 510512.

16. Kośc. Kolegialnemu Najśw. Maryi P. w Beaune we Francji, dn. 10 sierpnia 1957 r. N. 12-13, pp. 555-557.

17. Kośc. koleg. Najśw. Maryi P. ,de Ocotlan” w Meksyku, dn. 23 listopada 1957 r. N. 12-13, pp. 558, 559.

18. Kośc. św. św. Piotra i Aleksandra w Asciburgi diec. Herbipolensis, dn. 17 stycznia 1958 r. N. 14, pp .670, 671.

19. Kośc. Najśw. Maryi P. Dobrej Nadziei w Hainaut diec. Tornacensi, dn. 26 kwietnia 1957 r. N. 17, pp. $847,848$.

20. Kośc. Przenajśw. Trójcy w Krakowie, dn. 26 lipca 1957 r. N. 17, pp. $850,851$.

21. Kośc. Domini Boni Jesu w archidiec. Marianensis, dn. 26 lipca 1957 r. N. 19, pp. 930, 931.

22. Kośc. katedr. w diec. Pontiscurvi we Włoszech, dn. 15 marca 1958 r. N. 19, pp. 933, 934.

23. Kośc. katedr. w Tudertinum we Włoszech, dn. 16 marca 1958 r. N. 19, pp. 934, 935.

24. Kośc. katedr. w Trajana we Włoszech, dn. 28 marca 1958 r. N. 19, pp. 936, 937. 
25. Kośc. Najśw. Maryi P. Cremensis we Włoszech, dn. 18 kwietnia 1958 r. N. 19, pp. 937, 938.

26. Kośc. św. Piusa $X$ w Lourdes, dn. 7 maja 1958 r. N. 19, pp. 938, 939.

27. Kośc. par. w diec. S. Pauli w Brazylii, dn. 13 maja 1958 r. N. 19, pp. 939-941.

28. Kośc. Najśw. Maryi P. w diec. Nowariensis we Włoszech, dn. 20 czerwca 1958 r. N. 20, pp. 1023, 1024.

29. Kośc. Najśw. Maryi P. w diec. Asturiensis w Hiszpanii, dn. 12 lipca 1958 r. N. 20, pp. 1024, 1025.

\section{b) Ogtoszenia patronami.}

1. Najśw. Maryi P. Różańcowej - diec. Zacapensi w Gwatemali, dn. 30 marca 1957 r. N. 4, pp. 146, 147.

2. Sw. Sebastiana męcz. - milicji miejskiej, dn. 3 maja 1957 r. N. 4, pp. 148, 149.

3. Najśw. Maryi P. i św. Michała Archanioła - diec. Uruguaianensi w Brazylii, dn. 7 czerwca 1957 r. N. 5, pp. 195, 196.

4. Najśw. Maryi P. Karmelitańskiej - diec. Jaboticaballesi w Brazylii, dn. 13 czerwca 1957 r. N. 5, pp. 197, 198.

5. Sw. Jana Gualberta - leśników w Brazylii, dn. 24 kwietnia 1957 r. N. 6-7, pp. 252, 253.

6. Najśw. Maryi P. Niepok. Pocz. - archidiec. Gualaiarensis w Meksyku, dn. 5 lipca 1957 r. N. 6-7, pp. 302, 303.

7. Św. Michała Archanioła - Bankowców we Włoszech, dn. 3 września 1957 r. N. 8, pp. 355, 356.

8. Sw. Wincentego Marie Strambi - diec. Maceratensis i Tolentinae, dn. 7 września 1957 r. N. 8, pp. 357, 358.

9. Sw. Kryspina męcz. - miasta Porto S. Elpido w archidiec. firmańskiej, dn. 23 września 1957 r. N. 8, pp. 359,360 . 
10. Sw. Benedykta opata - mechaników i architektów, dn. 29 listopada 1957 r. N. 9, pp. 443, 444.

11. Najśw. Maryi P. - misji w Ekwadorze, dn. 3 marca 1957 r. N. 9-10, pp. 464, 465.

12. Najśw. Maryi P. i Patrycjusza wszystkich sztuk, dn. 19 lipca 1957 r. N. 9-10, pp. 467, 468.

13. Sw. Marii Magdaleny - diec. Afogadensis w Brazylii, dn. 9 sierpnia 1957 r. N. 9-10, pp. 470, 471.

14. Św. Jana Bosko - młodzieży rzemieślniczej, dn. 17 stycznia 1958 r. N. 9-10, pp. 474, 475.

15. Sw. Klary - telewizji, dn. 14 lutego 1958 r. N. 11, pp. 512, 513 .

16. Ŝw. Józefa - diec. Tamatavensi, dn. 8 września $1957 \mathrm{r}$. N. 12-13, pp. 557, 558.

17. Najśw. Maryi P. Różańcowej i św. Józefa - diec. Gualeguaychunensis, dn. 30 listopada 1957 r. N. 12, p. 560 .

18. Najśw. Maryi P. Wspomożycielki Wiernych i św. Leona - opactwa De Belmont w Stanach Zjednoczonych Am. Płn., dn. 5 grudnia 1957 r. N. 12-13, pp. 621, 622.

19. Sw. Piotra - diec. Mariliensis, dn. 30 grudnia $1957 \mathrm{r}$. N. 14-15, pp 668, 669

20. Najśw. Maryi P. Różańcowej i św. Barbary — archidiec. Manizalensis, dn. 9 stycznia 1958 r. N. 14-15, pp. 669,670 .

21. Najśw. Maryi P. - kolegium ,Union Nacional Espanda de los Resineros", dn. 28 lutego 1958 r. N. 14-15, p. 672 .

22. Najśw. Maryi P. - miasta Ponferrada i okolicy El Bierzo w Hiszpanii, dn. 5 marca 1958 r. N. 14-15, pp. $673,674$.

23. Najśw. Maryi P. a Lapurdo - pasterzy włoskich, dn. 11 lipca 1958 r. N. 17, pp. '848, 849.

24. Najśw. Maryi P. Różańcowej i św. Serapiona - diec. Azulensis, dn. 2 sierpnia 1957 r. N. 17, p. 852. 
25. Najśw. Maryja P. z Góry Karmelu - prałatury udzielnej Sancti Ferdinandi Apurensis, in Venetiola, dn. 8 września 1957 r. N. 19, p. 932.

c) Ogloszenia różne.

1. Nowego stopnia odznaczenia "Torques Aureus", dn. 25 grudnia 1957 r. N. 1, pp. 29, 30.

2. Dołączenie Pólwyspu Malajskiego do delegatury apostolskiej Thailandesi, dn. 27 listopada 1957 r. N. 6-7, pp. 251, 252.

3. Teresy od Jezusa Jornet Ibars błogosławioną, dn. 27 kwietnia 1958 r. N. 6-7, pp. 306-309.

E. Epistulac.

1. Do J. Em. Waleriana Kard. Valeri z okazji 50-lecia jego kapłaństwa, dn. 12 grudnia 1957 r. N. 1, pp. 30, 31.

2. Do Magnif. P. Aug. Gemelli, rektora uniw. Najśw. Serca Jezusowego w Mediolanie, dn. 8 grudnia $1957 \mathrm{r}$. N. 2-3, pp. 66, 67.

3. Do J. Em. Piotra Kard. Fumasoni Biondi z okazji 25lecia jego kardynalatu i prefektury w św. Kongr. Rozkrzewienia Wiary, dn. 4 marca 1958 r. N. 5, p. 201.

4. Do J. Em. Eliasza Kard. Dalla Costa z okazji 25-lecia jego kardynalatu, dn. 4 marca 1958 r. N. 5, pp. 202, 203.

5. Do J. Em. Mauryliusza Kard. Fossati z okazji 25-lecia jego kardynalatu, dn. 4 marca 1958 r. N. 5, p. 203.

6. Do J. Em. Fryderyka Kard. Tedeschini z olkazji 25lecia jego kardynalatu, dn. 12 marca 1958 r. N. 5, pp. 204, 205.

7. Do J. Ex. Ryszarda Cushing, arcybpa Bostonu z okazji 150-lecia jego archidiec., dn. 22 lutego $1958 \mathrm{r}$. 6-7, pp. 253, 254. 
8. Do J. Em. Franciszka Kard. Spellmana z okazji 150lecia jego archidiec., dn. 28 lutego 1958 r. N. 6-7, pp. 255, 256.

9. Do J. Ex. Jana Floersh z okazji 150-lecia jego archidiec., dn. 10 marca 1958 r. N. 6-7, pp. 257, 258.

10. Do J. Ex. Jana O'Hara z okazji 150-lecia jego archidiec., dn. 12 marca 1958 r. N. 6-7, pp. 258, 259.

11. Do J. Ex. Hamleta Cicognani z okazji 25-lecia jego biskupstwa, dn. 10 kwietnia 1958 r. N. 6-7, p. 260.

12: Do J. Ex. Henryka Chappoulie z okazji 100 rocznicy pierwszego Kongresu ,L'Union des Oeuvres Catholiques de France", dn. 1 kwietnia 1958 r. N. 6-7, pp. 310,311 .

13. Do zakonników zgromadzonych na Kongresie w Olysipone w Portugalii, dn. 3 kwietnia 1958 r. N. 6-7, pp. $312-318$.

14. Do J. Em. Jerzego Kard. Grente z okazji 40-lecia jego biskupstwa, dn. 15 maja 1958 r. N. 9-10, pp. 445, 446.

15. Do J. Em. Pawła Kard. Leger. mianując go legatem na urcczystość do Beaupre' w Kanadzie, dn. 24 czerwca 1958 r. N. 9-10, pp. 477, 478.

16. Do J. Em. Józefa Kard. Siri, mianując go legatem do Brukseli, dn. 24 lipca 1958 r. N. 12-13, pp. 561, 562.

17. Do J. Em. Eugieniusza Kad. Tisserant, mianując go legatem na dwa Kongresy Maryjne do Lourdes, dn. 2 sierpnia 1958 r. N. 14-15, pp. 722, 723.

18. Do O. Lombardi Ryszarda S. J., dn. 26 sierpnia 1058 r. N. 14-15, pp. 724, 725 .

19. Do J. Em. Karola Kard. De La Torre, mianując go legatem na Kongres Euch. do Ekwadoru, dn. 28 sierpnia 1958 r. N. 14-15, pp. 725, 726.

20. Do J. Ex. Arcybp. Reims z racji odbudowania bazyliki św. Remigiusza, dn. 29 września 1958 r. N. 19, pp. 941,942 . 
E. U mow y.

1. Stolicy Ap. z Boliwią, dn. 1 lutego 1958 r. N. 2-3, pp. 68-81.

Umowa St. Ap. z Boliwią w 20 art. normuje prace misjonarzy i organizację Kościoła na tych terenach.

G. Przemówienia.

1. Do uczestników trzeciego Kongresu Sodalicji Włoskiej pro Consilio Municipiorum Europae, po fran., $\mathrm{dn}$. 3 grudnia 1957 r. N. 1, pp. 31-33.

2. Do uczestników powszechnego Kongresu Stanów doskonatości zakonnej, odbytego $w$ Rzymie 9 grudnia 1957 r., po fran., N. 1, pp. 34-43.

Problem doskonałości, odnowy i przystosowania środków, przy pomocy których dążą do niej jednostki i Zgromadzenia zgrupowane $w$,stany doskonałości". Pojęcia „doskonałość" nie można utożsamiać $z$ pojęciem „stanu doskonałości”. Można spotkać heroiczną doskonałość chrześcijańską, ewangeliczną poza wszelkim ,stanem doskonałości”. Dążenie do doskonałości to stałe usposobienie duszy chrześcijańskiej, nie zadawalniającej się wypełnieniem swych obowiązków, ona kochając Boga, oddaje się służbie bliźniego. Dążność do doskonałości jest obowiązkiem pod karą chybienia swego celu ostatecznego. Ideał doskonałości chrześcijańskiej wiąże się $z$ nauką Chrystusa. Dążeniem do tego ideału jest powołaniem każdego chrześcijanina, który winien poświęcić mu wszystkie swe siły, ale realizuje się go $\mathrm{w}$ sposób zupełny i bardziej pewny $w$ trzech stanach doskonałości według zasad określonych przez Prawo Kanoniczne i trzy szczególnie Konst. Apost. „Provida Mater” z dnia 2 lutego 1947 r. "Sponsa Christi" i „Sedes Sapientiae”.

7. Do przełożonych zakonów, po łacinie, dn. 11 lutego 1958 r. N. 4, pp. 153, 154. 
Przełożony w kierowaniu innymi ma być łagodny i roztropny, a w cichości i pokorze stateczny, bo ojcowskimi normami kieruje współbraćmi do Boga, który jest celem nas wszystkich.

8. Do proboszczów $i$ kaznodziejów wielkopostnych $w$ Rzymie, po wlosku, dn. 18 lutego 1958 r. N. 4, pp. 161 -169 .

Rzym jest stolicą chrześcijaństwa, centrum życia religijnego i moralnego. $\mathrm{Na}$ wieczne miasto zwrócone oczy wszystkich. Z okazji setnej rocznicy Objawień w Lourdes odbędą się misje. Aby owoc tych misji był trwały, pogłębił życie religijne i moralne, by w każdej duszy zamieszkał Bóg - oto cel duszpasterzy.

9. Do kolejarzy $z$ calych Wloch zgromadzonych $w$ Rzymie $z$ racji pielgrzymki, po włosku, dn. 22 lutego 1958 r. N. 4, pp. $170-174$.

Każdy podróżny musi mieć swój cel dokąd zdąża. Dla każdego też $\mathrm{w}$ pociągu jest zarezerwowane miejsce, pewne wygody i przyjemności. Co można powiedzieć o człowieku, który nie znajdując wygód i przyjemności w swym pociągu, wsiada do drugiego idącego w przeciwnym kierunku.

To samo nieraz dzieje się $\mathrm{w}$ życiu duchowym człowieka, który jak ten podróżny, wybiera wygody i łatwiznę $w$ życiu, stąd nie może dotrzeć do swego celu, jakim jest Bóg.

10. Do robotników $z$ Neapolu i prowincji zgromadzonych $z$ racji pielgrzymki, po włosku, dn. 9 marca $1958 \mathrm{r}$. N. 5, pp. 205-212.

Ziemia, niebo i morze złożyły się na piękno Neapolu i jego okolic, jednak mimo swego piękna i zachwytu poetów i malarzy całego świata, stanął przed trudnym problemem zacofania gospodarczego, zniszczenia i ruiny.

Kościół i państwo idą w parze by rozwiązać ten trudny problem. Wiele już zrobiono, ale wiele jeszcze pozostaje do zrobienia. Każdy mieszkaniec Neapolu dum- 
ny ze swego miasta i jego historii, będzie umial wytrwać w wierze swych ojców, mimo trudu i samozaparcia się, wiedząc, że za wspaniałymi placami i słynnymi ulicami znajdują się ciasne uliczki i ślepe załuki. Nie będzie burzyl pierwszych lecz przebudowywal drugie na nowoczesne, wspaniałe przedmieścia.

11. Do Mtodzieży z Sodalicji w Akcji Katolickiej, po włosku, dn. 19 marca 1958 r. N. 5, pp. 212-216.

12. Do Sodalicji z okolic Piceny, po włosku, dn, 23 marca 1958 r. N. 5, pp. 216-220.

13. Do rodzin, które utracity $w$ czasie wojny swych bilskich i do tych, co nie moga powrócić do swej ojczyzny, po włosku, dn. 30 marca 1958 r. N. 6-7, pp. 265-267. Nie usłuchano glosu Ojca, wzgardzono jego prośbami i upomnieniami. Przyszla istraszna wojna, obróciła w perzynę wiele miast, pozostawila po sobie dużo wdów i sierot. Wielu nie wróciło do swych najbliższych. To stało się dla niewierzących powodem bólu i rozpaczy, a dla wierzących przyczyną łez i smut$\mathrm{ku}$, ale i nadziei na lepsze życie, przyszłe, nieśmierteline.

14. Do zgromadzonych na XIII zjazd Stowarzyszesia miedzynarodowego „de Psychologie appliquée” po francusku, dn. 10 kwietnia 1958 r. N. 6-7, pp. 268-282.

15. Do zgromadzonych na zjazd wiedzy o Zakonach Wschodnich, po francusku, dn. 11 kwietnia $1958 \mathrm{r}$. N. 6-7, pp. 282-286.

16. Do Delegatów z Afryki $i$ mężów Instytutu „Centre de Documentation et de Diffusion des Industries Minerales et Energetiques d'Outre Mer", po francusku, dn. 13 kwietnia 1958 r. N. 6-7, pp. 286, 287.

17. Do uczestników XII zjazdu Włoskiego Narodowego Stowarzyszenia Rolników, po włosku, dn. 16 kwietnia 1958 r. N. 6-7, pp. 287-291. 
Pizez każdą pracę możemy okazać miłość Boga i bliźniego. Piękne są wasze cele: polepszyć byt pracowników rolnych przez słuszną i zdrową reformę rolną, przez postęp w dobrobycie materialnym osiągnąc postęp duchowy, wreszcie dać przykład innym, jak po chrześcijańsku rozwiązuje się trudności socjalne. Pracownicy rolni byli i są, i muszą pozostać bazą zdrowych zasad socjalnych i moralności.

18. Do uczestników IV zjazdu Wtoskiej Federacji Narodowej Maryjnej, po włosku, dn. 26 kwietnia 1958 r. N. 6-7, pp. 318-322.

Najśw. Maryja P. ma być przykładem, jak żyć w Kościele Chrystusowym. Od Niej należy się uczyć, jak żyć wiarą, Jej „fiat" ma stać się naszym, by pełnić zawsze wolę Bożą. Kościół ma dziś specjalną misję udowodnienia, że tylko i wyłącznie nauka Chrystusowa zdolna jest ożywić i wyrwać świat spod ciężaru niepokoju.

19. Do uczestników $w$ czasie uroczystości beatyfikacyjnych Teresy od Jezusa Jornet Ibars, po hiszpańsku, dn. 28 kwietnia 1958 r. N. 6-7, pp. 322-325.

20. Do Kierowników Wioskiej Organizacji Opieki nad Sierotami Robotnikami, po włosku, dn. 29 kwietnia 1958 r. N. 8, pp. 361-364.

Misja wasza piękna i wzniosła, bo macie zastąpić rodziców tym, na głowach których nigdy może nie spoczęła pieszczotliwa ręka ojca czy matki. Chcecie wpoić wszystkim ludziom potrzebę braterskości, obowiązek sprawiedliwości i miłości. Szczególne pragnienie sprawiedliwości socjalnej nad młodzieżą pracującą osieroconą i uciśnioną przez nowe wymogi ekonomiczne. Oto najgłębszy sens życia chrześcijańskiego według słów św. Jakuba 1, 27: „Czystą i nieskalaną pobożnością wobec Boga i Ojca jest nawiedzanie sierot i wdów $\mathrm{w}$ utrapieniach ich i strzeżenie samego siebie od zma- 
zy tego świata". Powinni wszyscy zrozumieć, że więcej niż pożywienia czy ubrania, sierota potrzebuje gorącej i głębokiej dobroci oraz zapewnienia, że przyjdzic i dla niej lepsze jutro świetlane.

21. Do uczestników zjazdu Stowarzyszenia Katolickich Robotników Włoskaich (A.C.L.I.) z Rzymu $i$ okolicy, po włosku, dn. 1 maja 1958 r. N. 8, pp. 365-369.

Dzień 1 maja poświęcony św. Józefowi, patronowi robotników. Długie lata walczono o prawo dla ludzi pracy. W walce tej znajduje się niezapomniany Leon XIII, nieśmiertelny pioner o nowy porządek społeczny w swej „Rerum novarum". Stowarzyszenie katolickich robotników ma dalej kontynuować tę walkę o swe prawa, ma stać się szkołą robotnika chrześcijanina. Dla każdego z was, według słów waszego hymnu, ma być cel jasny pokoju i pracy, przewodnik pewny - Chrystus Zbawiciel.

22. Do kierowników Organizacji Paktu Pólnocno-Atlantyckiego (NATO), po angielsku, dn. 16 maja $1958 \mathrm{r}$. N. 8, pp. 369, 370.

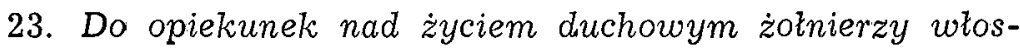
kich, po włosku, dn. 21 maja 1958 r. N. 8, pp. 370373.

Nauka katolicka nie akceptuje doktryny wojny. Chrześcijaństwo uważa ludzkość za jedną wielką rodzinę, stąd jest przeciwne wojnie agresywnej, gdzie brat zabija brata. Kościół odrzuca wszelką doktrynę, która utrzymuje, że wojna jest efektem koniecznym sił kosmicznych, fizycznych, biologicznych czy ekonomicznych. Kościół jednak nie potępia wojny sprawiedliwej, kiedy to nieograniczona wolność ludzka zdolna jest wywołać niesprawiedliwy konflikt, napadając na naród, który w określonych warunkach może chwycić za oręż i bronić swych praw.

Wystąpienie Kaina przeciw Ablowi, dwóch braci, napastnik i napadnięty, oto początek walk i wojen, hi- 
storia krwi $\mathrm{i}$ lez, historia ruiny i śmierci. Wyrwani młodzi ludzie $z$ pieleszy domowych idą do koszar, by w twardej szkole życia nauczyć się techniki walk. Opuszczają swych najbliższych a idą wśród obcych, gdzie nieraz znajdą się $\mathrm{w}$ niebezpieczeństwie duchowym. Kapelan wojskowy ma być im proboszczem, a wy matkami i siostrami.

24. Do zgromadzònych na II Kongres Wloskiej Fedieracji Pośredników i Agentów, po włosku, dn. 22 czerwca 1958 r. N. 11, pp. 514-518.

Instytucja pośrednictwa wywodzi się $\mathrm{z}$ prawa rzymskiego, od fideiussio- poręczenie. W okresie prawa klasycznego, instytucja ta miała piękne i szlachetne cele, likwidowanie sprzeczek między przyjaciółmi. Pośrednictwo jest kontraktem, w którym $\mathrm{z}$ jednej strony pośrednik przyabiecuje swoją czynność w załatwieniu interesów strony drugiej, a ta w zamian przyobiecuje pewne wynagrodzenie. W swych czynnościach nie dajcie się sprowadzić na nieuczciwe drogi $\mathrm{w}$ traktowaniu klienta czy właściciela. Waszą zasadą, będzie zasada moralności katolickiej, a nie „business is business", bo doskonałym pośrednikiem między ludzmi a Bogiem, to Chrystus.

25. Do uczestników XII zjazdu stowarzyszenia „Oto-Rhino-Laryngologica Latina", po francusku, dn. 29 czerwca 1958 r. N. 11, pp. 518-523.

26. Do niewast wloskich $z$ Akcji Katolickiej $z$ racji 50lecia ich zrzeszenia, po włosku, dn. 2 lipca 1958 r. N. 11 , pp. $523-530$.

Obowiązkiem niewiast katolickich jest, by ojczyzna ich była katolicka.

27. Do Wloskiej Sodialicji Żeńskiej w Akcji Katolickiej $z$ racji ich 40-lecia istnienia, po wlosku, dn. 13 lipca 1958 r. N. 11, pp. $530-535$. 
28. Do uczestnikó wmiędzynarodowego zjazdu członków trzeciego zakonu św. Dominika, po francusku, dn. 29 sierpnia 1958 r. N. 14-15, pp. 674--679.

29. Do uczestników VII międzynarodowego zjazdu rcheologów, po francusku, dn. 7 września 1958 r. N. 1415, pp. 679-683.

30. Do uczestników międzynarodowego zjazdu urzędników sqdowych, po francusku, dn. 8 września 1958 r. N. 14 -15, pp. 683-687.

31. Do uczestników zjazdu „Collegio Internationali Neuro-Psycho-Pharmacologico", po francusku, dn. 9 września 1958 r. N. 14-15, pp. 687-690.

32. Do uczestników „Office International de l'Enseignement Catholique", po francusku, dn. 14 września 1958 r. N. 14-15, pp. 696-700.

33. Do uczestników VII Kongresu, ,Societate internationali pro sanguinis transfusione", po francusku, dn. 5 września 1958 r. N. 14-15, pp. 726-732.

34. Do uczestników VII międzynarodowego kongresu hematologów, po francusku, dn. 12 września $1958 \mathrm{r}$. N. 14-15, pp. $732-740$.

H. Przemówienia radiowe.

1. Urbi et Orbi z okazji Bożego Narodzenia, po włosku, dn. 22 grudnia 1958 r. N. 1, pp. 5-24.

Mimo nowych zdobyczy wiedzy i techniki, dręczący niepokój ogarnia człowieka, bo dostrzega $w$ kosmosie tylko dysharmonię. Stąd rodzi się nieusprawiedliwiony pesymizm u jednych, czy tępa rezygnacja u drugich, bo zapatrzeni $\mathrm{w}$ wielkość człowieka nie widzą wielkości Boga. Chrystus źródłem harmonii i pocieszycielem, rękojmią zbawienia i odrodzenia. On światłem i życiem. Stąd chrześcijanin... nigdy nie poddaje 
się pesymizmowi czy biernej rezygnacji, on uczestniczy w utrzymaniu ladu i porządku, który jest celem wszystkich ludzi dobrej woli.

2. Do alumnów szkót katolickich Stanów Zjednoczonych Am. Pln., zachęcając ich do chrześcijańskiej ofiarności wobec mlodzieży potrzebującej, po angielsku, dn. 19 lutego 1958 r. N. 4, pp. 174-176.

3. Do wiernych $z$ okazji Zmartwychwstania Pańskiego, po włosku, dn. 6 kwietnia 1958 r. N. 6-7, pp. 261-264. „Jam jest światłością świata, kto idzie za mną, nie chodzi w ciemnościach, ale będzie miał światłość żywota" - J. 8, 12.

4. Do wiernych $z$ Sardynii $z$ okazji 50-lecia ogłoszenia patronka wyspy Najśw. Maryi P., po wlosku, dn. 24 kwietnia 1958 r. N. 6-7, pp. 326-330.

5. Do mniszek klauzurowych, po francusku, dn. 19 i 25 lipca oraz 2 sierpnia 1958 r. N. 12-12, pp. 562-586.

6. Do ogólnego zjazdu Federacji Katolickiej „De Sanitäte" odbytego $\mathrm{w}$ bazylice Najśw. Serca Jezusowego w Brukseli, po francusku, dn. 27 lipca 1958 r. N. 12-13, pp. 586-593.

7. Do wiernych narodu niemieckiego zebranych na 78 Katholikentag $w$ Berlinie, po niemieckie, dn. 17 sierpnia 1958 r. N. 14-15, pp. 701-705.

Miasto, w którym zebrali się wierni Berlina, rozdarte na dwa światy; na Wschód i Zachód, lecz cały świat należy do Boga, u którego trzeba szukać pomocy w modlitwie i ofierze. Dzień ten ma stać się dniem koegzystencji wszystkich $w$ prawdzie i lasce, ma stać się dniem troski o człowieka i chwałę Bożą. Niechaj więc lączy wszystkich jedna wiara.

8. Do zgromadzonych na międzynarodowym Kongresie Maryjnym $w$ Lourdles, po francusku, dn. 17 września 1958 r. N. $14-15$, pp. $741-745$. 
9. Do wiernych Ekwadoru zebranych na III Kongresie Eucharystycznym $w$ Guayaquil, po hiszpańsku, dn. 28 września 1958 r. $14-15$, pp. 745-748.

I. Nuntii scripto dati.

1. Do uczestników ogólnego zjazdu stowarzyszenia „Familia” w bazylice Najśw. Serca Jezusowego w Paryżu, po francusku, dn. 10 czerwca 1958 r. N. 9-10, pp. $446-448$.

2. Do pracowników $z$ Akcji Katolickiej z Francji i innych narodowości przybyłych do Lourdes, po francusku, dn. 21 lipica 1958 r. N. 12-13, pp. 592, 593.

3. Do zebranych na uroczystościach $\mathrm{W}$ Brukseli, po francusku, dn. 15 sierpnia 1958 r. N. 12-13, pp. 622-625.

J. Sacra Consistoria.

1. Dnia 9 czerwca 1958 r. N. $9-10$, pp. $393-442$.

\section{Acta Joannis Papae XXIII.}

Ogłoszenie wyboru Papieża przez J. Em. Mikołaja Kard. Canali, dn. 28 października 1958 r. o godz. 18,05, N. 17, p. 837.

Annuntio Vobis Gaudium Magnum - Habemus Papam

Emum ac Rmum Dominum S. R. E. Cardinalem

Angelum Josephum Roncalli

Qui Sibi Nomen Imposuit

Jo a n n em XXIII.

1. Urbi et Orbi przemówienie radiowe Ojca św. Jana XXIII $z$ okazji wyboru na papieża, dn. 29 października 
1958 r. N. 17, pp. 838-841. Błogosławiąc wszystkim, zachęca by zechcieli prosić Opatrzność Bożą o laskę i błogosławieństwa, aby stała się ,,jedna owczarnia i jeden pasterz" J. 10, 16 oraz by zapanował pokói Chrystusowy na ziemi.

\section{Acta SS. Congregationum}

A. Suprema S. C. S. Officii.

a) Upomnienia.

1. Z racji wprowadzenia nowych modlitw, co zarezerwowane jest St. Ap., dn. 14 lutego 1958 r. N. 2-3, p. 114

2. By chrzcić dzieci jak najprędzej w myśl kan. 770, dn. 18 lutego 1958 r. N. 2-3, p. 114.

3. Z racji puszczania we Mszy św. $\mathrm{w}$ Wielkim Tygodniu „Mysterium Fidei” przy konsekracji kielicha, dn. 24 lipca 1958 r. N. 11, p. 536.

B. Sacra Congregatio Consistorialis.

a) Zmiany granic.

1. Diec. Almeriensis i Granatensis w Hiszpanii, dn. 10 lipca 1957 r. N. 1, pp. 44, 45.

2. Diec. Conchensis i Rivibambensis w Ekwadorze, dn. 29 grudnia 1957 r. N. 5, pp. 226, 227.

3. Diec. Mariliensis i Corumbensis w Brazylii, dn. 2 lutego 1958 r. N. 6-7, pp. 331, 332.

4. Archidiec. S. Ludovici i prałatury udzielonej Pinerensis w Brazylii, dn. 24 lutego 1958 r. N. 9-10, pp. 485,486 .

5. W 10 diec. w Brazylii, dn. 14 lutego 1958 r. N. 11, pp. $436-439$. 
6. Archidiec. Mechliniensis i diec. Gandavensis w Belgii, dn. 24 lutego 1958 r. N. 11, pp. 539, 540.

7. Diec. Campaniensis i Guaxupensis w Brazylii, dn. 3 marca 1958 r. N. 11, pp. 540, 541.

8. Archidiec. Goritiensis i diec. Tergestinae we Wloszech, dn. 17 marca 1958 r. N. 12-13, pp. 627-629.

9. Archidiec. Bellahorizontinae i deic. Oliveirensis w Brazylii, dn. 26 kwietnia 1958 r. N. 14-15, pp. 706, 707.

10. W jednej archidiec. i czterech diec. w Hiszpanii, dn. 30 kwietnia 1958 r. N. 14-15, pp. 707-709.

11. Prałatur udzielnych Registrensis i Chapadensis w Brazylii, dn. 19 maja 1958 r. N. 14-15, pp. 709, 710.

b) Przeniesienia.

1. Katedry metropolitalnej Cincinnatensis, dn. 1 sierpnia 1957 r. N. 1, pp. $45,46$.

2. Katedry bp. Duluthensis, dn. 1 września 1957 r. N. 2-3, pp. 115.

3. Zamieszkania bpa $w$ diec. Cerinolensis do Asculanae Apuliae, dn. 14 stycznia 1958 r. N. 8, p. 384.

c) Prowizje.

1. N. $2-3$, pp. 97,98 .

2. N. 5, pp. $221-225$.

3. N. 8, pp. $374,375$.

4. N. $9-10$, pp. 479,480 .

5. N. $12-13$, pp. 626,627 .

6. N. $14-15$, pp. 749,750 .

d) Zmiany nazw.

1. Diec. Altunensis na Johnstoniensis w Stanach Zjednoczonych Am. Płn., dn. 9 października 1957 r. N. 4, pp. $177,178$. 
2. Diec. Sancti Caroli de Pinhal na Sancti Caroli w Brazylii, dn. 25 listopada 1957 r. N. 5, pp. 225, 226.

3. Diec. Tamaulipana na Tampicensis, dn. 25 lutego 1958 r. N. 8, p. 385.

4. Diec. Portus Gratiae na Portus Gratiae-Grandfallensis w Kanadzie, dn. 22 lutego 1958 r. N. 9-10, p. 484.

5. Prałatury udzielonej S. Peregrini Latiosi na Acrensis et Puruensis w Brazylii, dn. 26 kwietnia $1958 \mathrm{r}$. N. 12 - 13, pp. $629,630$.

e) Różne.

1. Dekret o połączeniu kurii diecezjalnych Terracinensis, Privernensis i Sentinae, dn. 25 lipca 1957 r. N. 5, pp. 223, 224.

2. Zatwierdzenie uchwal Episkopatu Kolumbii, dn. 23 października 1957 r. N. 5, pp. 224, 225.

3. Wyznaczenie trybunału sądowego dla wik. wojskowego w Argentynie, dn. 16 grudnia 1957 r. N. 5, p. 227.

4. Przepisy duszpasterstwa dla pracujących na morzu, dn. 21 listopada 1957 r. N. 8, pp. 375-383.

5. Erygowanie wik. wojsk. w Republice Dominikańskiej, dn. 23 stycznia 1958 r. N. 9-10, pp. $480-483$.

6. Mianowanie wik. wojsk. w Republice Dominikańskiej, dn. 11 lutego 1958 r. N. 9-10, p. 483.

7. Wyznaczenie . trybunału . sądowego dla wik. wojsk. w Holandii, dn. 8 maja 1958 r. N. 14-15, pp. 710, 711.

D. Sacra. Congregatio de Religiosis.

1. Instrukcja 'o wychowaniu młodzieży w szkołach koedukacyjnych, dn. 8 grudnia 1957 r. N. 2-3, pp. $99-103$. 
2. Deklaracja. Na zapytanie Sióstr bez ślubów publicznych - czy dotyczy ich też Konst. „Sedes Sapientiae'. Affirmative, dn. 30 lipca 1957 r. N. 2-3, p. 103.

E. S. Congregatio de Propaganda Fide.

a) Zmiany nazw.

1. Pref. apost. De Akyab na Promensis w Birmie, dn. 19 września 1957 r. N. 2-3, p. 104.

2. Wik, apost. Likuniensis na Lilongwensem w Niasa Bryt. (Afryka), dn. 20 czerwca 1958 r. N. 11, p. 543.

b) Zmiany granic.

1. Diec. Visakhapatnamensem i Cuttackesem w Indiach, dn. 20 czerwca 1957 r. N. 2-3, p. 117.

2. Wik. apost. Djakartanum i pref. apost. Sakabumensem w Indonezji dn. 8 listopada 1957 r. N. 4, pp. 178, 179.

3. Wik. apost. Thanh-hoa i Vientianensi w Laosie, dn. 14 lutego 1958 r. N. 5, p. 229.

c) Prowizje i nominacje.

1. N. 5, pp. 228,229 .

2. N. 11, pp. $542,543$.

F. S. Congregatio pro Ecclesia Orientali.

1. Prowizja kościoła, N. 8, p. 385.

G. Sacra Congregatio Rituum.

a) Procesy beatyfikacyjne i kanonizacyjne.

1. S1. B. Doroty De Chopitea Villata, dn. 21 czerwca 1958 r. N. 1, pp. 46-49. 
2. Bł. Ks. Marcelego Józefa Benedykta Champagnat, dn. 21 czerwrca 1958 r. N. 1, pp. 49, 50.

3. B1. Joachimy De Vedruna wd. Mas, dn. 7 stycznia 1958 r. N. 4, pp. $179-181$.

4. Sł. B. Teresy od Jezusa Jornet Ibars, dn. 7 stycznia 1958 r. N. 5, pp. 230-232.

5. J. w. dn. 28 marca 1958 r. N. 6-7, pp. 332, 333.

6. St. B. Marii Teresy Zonfrilli, dn. 19 listopada 1957 r. N. 8, pp. 386-388.

7. Bl. Karola a Setia, dn. 7 stycznia 1958 r. N. 8, pp. $388-390$.

8. J. w. dn. 28 marca 1958 r. N. 9-10, pp. 486, 487.

9. Bł. Joachimy De Vedruna wd. Mas, 28 marca 1958 r. N. 9-10, pp. 488, 489.

10. SŁ. B. Ks. Dominika od Przenajśw. Sakramentu, dn. 29 maja 1958 r. N. 11, pp. 544-546.

11. St. B. Emanuela D'Alzon, dn. 29 maja 1958 r. N. 12-13, pp. $594-598$.

12. Bł. Józela Marii Tommasi, dn. 24 maja 1958 r. N. 14-15, pp. 711, 712 .

b) Dekrety.

1. O proporcji wosku pszczelnego lub oleju $\mathrm{w}$ świecach przeznaczonych do użytku liturgicznego, dn. 13 grudnia 1957 r. N. 1, pp. 50, 51.

Sw. Kongregacja Obrzędów $z$ racji na trudności zleciła biskupom, by ustalili ilość procentu wosku pszczelnego czy oleju w świecach.

2. Zezwolenie na powtórne poświęcenie popiołu przed Mszą św. wieczorową w Srodę Popielcową, dn. 5 lutego 1958 r. N. 2-3, P. 104. 
c) Instrukcje.

1) O odprawianiu Mszy św. przez kaptanów upośledzonych na wzroku, dn. 15. grudnia 1957 r. N. 1, pp. $51-54$.

Kapłan tracący wzrok uzyskuje od św. Kongr. Obrzędów przywilej odprawiania Mszy św. o Najśw. Maryi P. albo Mszy św. żalobnej - Missa quotidiana.

A) Mszę św. wotywną o Najśw. Mari P. bierze V-tą i zawsze w kolorze białym.

B) Jeśli może swobodnie czytać może inną wziąść Mszę św. o Najśw. Mari P. - jedną z czterech przypadających na pory roku.

C) Jeśli jest Msza św. Wotywna uroczysta - pro re gravi et publice - mówi jedną Orację, Gloria i Credo, chocìażby inni kapłani mieli jakąś komemorację lub kolektę nakazaną przez Ord.

D) We wszystkich innych wypadkach.

a. Oracja zawsze tylko jedna.

b. Gloria odmawia się:

1. Ilekroć przypada we Mszy św. z danego dnia wg Kalendarza Kościoła.

2. W rocznicę własnych święceń kapłańskich.

3. W soboty.

c. Credo:

1. Ilekroć przypada we Mszy św. z danego dnia wg Kalendarza Kościoła.

2. W rocznice własnych święceń kapłańskich.

d. W prefacji zawsze - Et Te in Veneratione - z wyjątkiem świąt Najśw. Maryi P., gdyż wțedy bierze z danego dnia.

e. Ostatnia Ewangelia zawsze św. Jana - In Principio. 
E) W trzy dni Wielkiego Tygodnia powinien powstrzymać się od odprawiania, a w Boże Narodzenie może odprawić trzy Msze św.

F) Mszę św. żałobną śpiewa lub czyta w dniach na które zezwalają rubryki Kalendarza Kościoła.

a. Może tak odprawić trzy w Dzień Zaduszny - Oracja Fidelium.

b. Zawsze tylko jedna Oracja.

c. Nie jest zobowiązany nigdy do Sekwencji - Dies Irae, jakokolwiek chór powinien odśpiewać.

Uwaga. W razie calkowitej utraty wzroku nie może poprzestać na przywileju powyższym, musi zaprzestać odprawiać i prosić Sw. Kongr. Sakramentów o nowy indult, po otrzymaniu którego obowiązany jest pod grzechem cieżkim odprawiać Mszę św. tylko w asyscie drugiego kapłana.

2) O muzyce $i$ liturgii, an. 3 września 1958 r. N. 12-13. pp. $630-663$.

Oto niektóre charakterystyczne zmiany.

a) Msza św. śpiewana.

1. Sanctus i Benedictus $w$ śpiewie gregoriańskim nie należy nigdy rozdzielać, w innych wypadkach można Benedictus śpiewać po konsekracji.

2. Po podniesieniu, jeśli nie śpiewa się Benedictus, należy zachować ciszę aź do Pater noster.

3. Ostatniego błogosławieństwa kapłan udziela głośno, by wszyscy wierni mogli słyszeć, a organ w tym czasie milknie.

b) Msza 'św. cicha.

Jeśli wierni nie śpiewają lub nie odmawiają wspólnych modlitw; organ powinien milczeć od wejścia kapłana do Ofer torium, od pierwszych wersetów przed Prefacją do Sanctus włącznie, od Pater noster do Agnus Dei włącznie, w czasie Comfiteor przed Komunią św. wiernych, w czasie Postcommunio i ostatniego blogosławieństwa. Radzi się by od konsekracji do Pater noster było zachowane milczenie. 
c) Msza św. recytowana.

Pater noster także można odmawiać wraz $z$ kapłanem aż do Amen, ale tylko po łacinie.

H. Sacra Congregatiode Se minariset Studiorum Universitatibus.

1. Dekret erekcyjny Uniwersytetu Sherbrookensis w Kanadzie, dn. 21 listopada 1957 r. N. 5, pp. 232-234.

2. List do Ord. o starannym nauczaniu języka łacińskiego w Seminariach, ıdn. 27 października 1957 r. N. 6-7, pp. $292-296$.

\section{Acta Tribunalium}

A. Sacra Paenitentiaria Apostolica.

Modlitwy Piusa XII.

1. Dla nauczających, po włosku, dn. 28 grudnia 1957 r. N. 2-3, pp. 118, 119.

2. Dla członków stowarzyszenia chrześcijańskiej rodziny, po włosku, dn. 30 grudnia 1957 r. N. 2-3. pp 119, 120.

3. Dla prawodawców i polityków, po włosku, dn. 27 stycznia 1958 r. N. 2-3, pp. 121, 122.

4. Dla wojsk argentyńskich, po hiszpańsku, dn. 27 stycznia 1958 r. N. 5, pp. 235, 236.

5. Dla dziew'cząt, po włosku, dn. 7 marca 1958 r. N. 6-7, pp. 334, 335.

6. Do św. Józefa Rzemieślnika, po włosku, dn. 11 marca 1958 r. N. 6-7, pp. $335,336$.

7. Dla więźniów, po włosku, dn. 10 kwietnia 1958 r. N. 6-7, pp. 336, 337.

8. Dla wiernych uczęszczających na misje ludowe, po włosku, dn. 21 marca 1958 r. N. 9-10, pp. 490, 491. 
9. Z racji Narodowego Kongresu Eucharystycznego, po wlosku, dn. 24 czerwca 1958 r. N. 11, pp. 547, 548.

10. Do Najśw. Maryi P., po wlosku, dn. 2 sierpnia 1957 r. N. 12-13, pp. 599, 600.

B. Tribunal Supremum Signaturae Apostolic a e.

1. Wezwanie sądowe w sprawie o nieważność małżeństwa Zannino-Michelli, dn. 25 czerwca 1958 r. N. 9-10, pp. 491, 492.

C. Sacra Romana Rota.

Wezwania sądowe $\mathrm{w}$ sprawie o nieważności małżeństwa.

1. Dentrice - Montano, dn. 16 grudnia 1957 r. N. 1, p. 55.

2. Uribe - Rodriquez, dn. 18 grudnia 1957 r. N. 1, p. 56.

3. Aicher - Scwarzkopf, dn. 7 marca 1958 r. N. 4, p. 182.

4. Sherry - Barnes, dn. 15 marca 1958 r. N. 5, pp. $236,237$.

5. Bertolo - Davey, dn. 21 kwietnia 1958 r. N. 6-7, p. 238.

6. Schaefer - Oust, dn. 29 kwietnia 1958 r. N. 6-7, p. 239.

D. Tribunal Primae Instantiae Vicariatus Urbis.

Wezwanie sądowe w sprawie o nieważność małżeństwa.

1. Szlachato - Dunco, dn. 15 marca 1958 r. N. 4, p. 183.

2. Risi - Taverna, dn. 15 marca 1958 r. N. 4, p. 194.

3. Greggi - Trybuchowicz, dn. 2 maja 1958 r. N. 8, p. 391.

4. Carli - Lupi, dn. 24 maja 1958 r. N. 8, p. 392.

5. Paolozzi - Carosio, dn. 17 lipca 1958 r. N. 11, pp. 548,549 . 


\section{Acta Officiorum}

Pontificia Commissio ad Redigendum Codicem Juris Canonici Orientalis.

D. An, vi can. $215 \S 2$,Licet charactere episcopali careant (Legati), praecedunt tamen omnibus Hierarchis, qui non sint cardinalitia dignitate insigniti", iidem Legati praecedant Patriarchis. R. Negative, cum nomine Hierarchae non veniat Patriarcha, ad normam Litterarum Apostolicarum „Postquam Apostolicis Litteris" diei 9 Februarii anni 1952, can. 306 $\S \S 2,4$.

Norma autem haec est: „Licet charactere episcopali careant, praecedunt tamen omnibus Hierarchis qui non sint cardinalitia dignitate insigniti, aut patriarchali, dummodo Patriarcha in proprio territorio degat et caeremoniis vel officiis proprii ritus praesit; sed hoc quoque in casu, Legati Patriarchis praecedunt si explicitum mandatum cum praecedentia pro particularibus actibus iis a Summo Pontifice commissum fuerit".

Dn. 23 czerwca 1958 r. N. 11, p. 550.

\section{Diarium Romanae Curiae}

A. Ojciec św. przyją na uroczystej audiencji.

a) Ambasadorów nadzwyczajnych i pełnomocnych dla złożenia listów uwierzytelniających.

1. Dr Bartolomeo Migone - Italia, dn. 27 stycznia 1958 r. N. 2-3, p. 123.

2. Dr Vasco Pereira Da Cunha - Portugalia, dn. 16 lutego 1958 r. N. 2-3, p. 123.

3. Dr Tomas Perez Tenreiro - Wenezuela dn. 19 kwietnia 1958 r. N. 5, P. 238. 
4. Dr Pedro Virgilio De Yurrita Maury - Gwatemala, dn. 7 lipca 1958 r. N. 9-10, p. 493.

5. Dr Santiago De Estrada - Argentyna, dn. 25 września 1958 r. N. $14-15$, p. 751.

6. Dr Fernando Diez De Medina - Boliwia, dn. 27 września 1958 r. N. 14-15, p. 751.

b) Posłów nadzwyczajnych i ministrów pełnomocnych do złożenia listów uwierzytelniających.

1. Mesfin Begashet - Abisynia, dn. 27 kwietnia 1958 r. N. $6-7$, p. 340 .

2. Dr Senjin Tsuruoka - Japonia, dn. 6 maja 1958 r. N. $6-7$, p. 340 .

3. Dr Mullath Kadingi Vellodi - Indie, dn. 19 sierpnia 1958 r. N. $12-13$, p. 664.

4. Prof. Colbert Bonhomme - Haiti, dn. 22 sierpnia 1958 r. N. $12-13$, p. 664.

c) Nominacje.

1. Ojciec św. Jan XXIII mianowal Sekretarzem Stanu J. Ex. Dominika Tardini, dn. 17 listopada 1958 r. N. 18 , pp. $905,906$.

B. Sacra Congregatio de Propaganda Fid e.

1. Mianowanie Ks. Prał. Maurycego Lacroix, wik. gen. dyrektorem Papieskiego Dzieła Rozkrzewienia Wiary we Francji, dn. 25 lutego 1958 r. N. 11, p. 551.

C. Sacra Congregatio Ritu um.

Daty posiedzeń i tematy obrad $w$ sprawach beatyfikacji i kanonizacji.

1. N. 6-7, pp. $340-342$.

2. N. 11, pp. $551,552$. 
D. Sekretariat Stanu Jego Swiątobliwości Piusa XII.

a) Wykaz nominacji i Odznaczeń.

1. N. $2-3$, pp. $123-136$.

2. N. 5, pp. $238-248$.

3. N. $6-7$, pp. $342-344$.

4. N. $9-10$, pp. $493-504$.

5. N. 11, p. 552 .

6. N. $12-13$, p. 664 .

7. N. $14-15$, pp. $751-760$.

8. N. 18 , pp. 907,908 .

b) Zawiadomienia o śmierci.

1. N. 2-3, p. 136.

2. N. 5, p. 248.

3. N. 9-10, p. 504.

Uwaga. Cały N. 16, pp. $761-836$ jest poświęcony pamięci Ojca św. Piusa XII, oraz prawie cały N. 18, pp. $853-903$ jest poświęcony aktom konklawe. 